\title{
Goffman goes rock climbing: Using creative fiction to explore the presentation of self in outdoor education.
}

\author{
Simon K. Beames \\ University of Edinburgh \\ Elizabeth C. J. Pike \\ University of Chichester
}

\begin{abstract}
Outdoor education literature has a recent history of examining its practice through a variety of sociological, philosophical, psychological, and anthropological lenses. Following this trend, this paper explores the face-to-face social interaction of a fictional introductory rock-climbing course. The analysis of this creative fiction draws on Erving Goffman's dramaturgical framework, as described in his book The Presentation of Self in Everyday Life (1959). The discussion highlights how participants and instructors on a practical skill development weekend are involved in the complex endeavour of projecting and sustaining impressions for each other. Goffman's concepts regarding the ways in which humans conceal and reveal information about themselves may offer outdoor education instructors and researchers a helpful perspective through which they can consider how individual participants' actions are influenced by the perceived expectations of the different audiences they encounter.
\end{abstract}

Outdoor education literature has a short, but rich, history of using philosophical (e.g. Hunt, 1990; Wurdinger, 1997; Allison, 2002), anthropological (e.g. Andrews, 1999; Bell, 2003; Venable, 1997), and sociological (e.g. Beames, 2005; Zink \& Burrows, 2006; Pike \& Beames, 2007) lenses to examine practice. Despite the attention given to traditional lines of enquiry, there remains much scope for new theoretical interpretation of the day-to-day issues faced by outdoor centre managers, instructors, and teachers. The outdoor education sector is faced with the challenge of being able to communicate effectively across disciplines, with professionals engaged in diverse practices (see Zink and Burrows, 2006).

This paper explores the sociological framework of dramaturgy, as conceptualised by the late Erving Goffman ${ }^{1}$. The rationale for such enquiry is a belief that in gaining a deeper theoretical understanding of their fieldwork, outdoor educators may be able to deliver more meaningful educational programmes. Although Goffman's own research concentrated on areas as diverse as rural villages, asylums, and casinos, we attempt to illustrate how the conceptual framework outlined in his seminal text The Presentation of Self in Everyday Life (1959), may offer helpful ways of examining the social interaction inherent in an outdoor education course.

1. The term dramaturgy was used by Martin (2001) in reference to outdoor education programmes in the Czech Republic that focus on integrating a range of social, physical, creative, and emotional/ reflection activities. Although Martin and Goffman use the same term, the meanings they ascribe to the term are quite different.
We present a fictional story based on an amalgamation of hundreds of days that we have spent teaching and learning rock climbing with secondary school and university students in North America, Asia, and Europe. This narrative provides the platform through which Goffman's framework is used to explore the complex social interaction that may take place on courses of this nature. The case will also consider implications for more general outdoor education practice, as well as limitations of applying the concepts outlined in The Presentation of Self in Everyday Life (1959).

\section{Background: Goffman and his dramaturgical framework}

Erving Goffman was born in Winnipeg, Canada in 1922. Despite starting his university career studying chemistry, he would go on to "leave an indelible mark on the history of sociology" (Smith, 2006, p. 14). The first sign of this imprint appeared when Goffman completed his doctoral studies of people living in the Shetland Islands. The dissertation reported on a 12 month sociological ethnographic study of the faceto-face interaction that took place in one small island community of a hundred homes. The findings of Goffman's (1953) PhD are argued to make a significant contribution to a "framework useful in studying interaction throughout our society" (p. 1).

Since then, Goffman has been labelled "the consummate sociologist" (Birrell \& Donnelly, 2004, p. 49). He was interested almost exclusively in the subtle nuances of human interaction that he called face work (Goffman, 1967). Goffman's principal interest was 
"face-to-face interaction, the minutiae of ordinary talk and activity" (Smith, 2006, p. 1). This position earned him some critics, in particular, theorists who believed that he did not give enough attention to the influence of power and social structure on shaping individuals' attitudes and actions (see Gouldner, 1970). Despite the absence of an explicit macro-perspective, we maintain that the theoretical concepts that Goffman developed from his extensive study of small group social encounters lend themselves well to the analysis of outdoor education practice.

We regard Goffman's writing style as being very accessible to non-sociologists. Indeed, a number of Goffman's terms, such as presenting fronts and saving face, have entered general vernacular. He published 11 books and countless papers from the 1950s until his death in 1982. Arguably, Goffman is best known for the concepts outlined in his book, The Presentation of Self in Everyday Life, first published in its entirety in 1959. The book makes use of the language of the stage, and employs such terms as actors, audiences, front stage, and back stage - all ideas that emerged from Goffman's (1953) PhD dissertation and which are developed in what follows.

Goffman (1959) perceived the self to be a product of the dramatic interaction between the actor and their audience, whereby people act in a manner to fit the expectations of those in their company. Seen this way, people are both actors and audiences simultaneously. From Goffman's perspective, an actor's identity is confirmed by playing the same part to the same audience on different occasions. Goffman (1967) described a person as "having face" when they effectively presented their ideal self, having "wrong face" when some information about a person is inconsistent with their self image, and being "out of face" when the self image is not that expected of a person in any given situation (pp. 5-9). When a person loses face, they may then try to save face by engaging in impression management, which involves the use of speech, gestures, and equipment in order to manage the impressions that they give to other people (Goffman, 1959; Donnelly, 2002).

We will illustrate these concepts through a carefully constructed fictional story of an outdoor education experience. We argue that the use of creative fiction is a natural extension of Goffman's (1959) analogy of "the world's a stage" (p. 254), as we now write our own script for the performance of the outdoor education practitioners and students who we have created. We justify this approach in what follows.

\section{Methodology: Creative fiction}

We contend that basing the analysis on creative fiction (as opposed to empirical data) allows the paper to focus more on examining the intriguing issues of identity (re)construction that Goffman's dramaturgical concepts bring to outdoor education practice, rather than on convincing the reader that they are reading an accurate factual account of a particular event. Creative fiction as a methodology is liberating in this respect, as it offers authors the freedom to create a story with the explicit aim of raising important questions for practitioners and theorists (Barone, 1997).

Sparkes (2002b) is clear that authors of "creative fiction may find it more difficult to find outlets for their work in mainstream academic journals" (p. 183). The key, then, is establishing the credibility and realness of the story through the rigorous crafting of events and characters, in order to effectively challenge readers to generalise from the tale and consider cases familiar to them in a new light. This is not to say that our story should be accepted uncritically. Whether the genre is creative fiction or ethnographic fiction, "no textual staging is innocent" (Sparkes, 2002b, p. 188). The credibility of the writing relies on "a kind of description that is accurate in a holistic, evocative, emotionally engaging sense" (Rinehart, 1998, pp. 2056)

Rinehart (1998) claims that "fiction and fictional devices may in fact be more effective in conveying certain aspects of lived experience" (p. 201). The common, and often messy, elements of qualitative research, such as data collection, analysis, and verification, may actually marginalise interpretations of the findings, as the considerable attention needed to establish the credibility of the data may result in less emphasis being placed on considering the data's usefulness for academic discourse. Furthermore, in much empirical qualitative enquiry it is common ethical practice to protect the identity of an investigation's participants through various means. Apart from changing their names, it is often necessary to change geographic locations, institutional names, and possibly "fudge" who said what - all in an attempt to ensure the anonymity of the participants and, indeed, the authors (Coffey \& Atkinson, 1996).

Barone (2000) explains how writers using creative fiction are less interested in accurately recreating people, places, and events. Fictional accounts may offer clearer portrayals of situations that can then be used for analysis and discussion (Tierney, 1993). Sparkes (2002a) states that "all forms of research writing draw on fictional techniques" (p. 2). Although creative fiction makes no claim to draw on specific empirical data, we have witnessed the events in the following story over the last fifteen years and all of the characters are composites of real people. This story 
is based on the authors "being there' in the action" (Sparkes, 2002b, p. 153), and the events having been "shaped and dramatized using fictional techniques" (Sparkes, 2002a, p. 5).

Ultimately, the use of creative fiction is only warranted "when employed in the service of a legitimate research purpose. That purpose is the generation of a conversation about important educational questions" (Barone, 1997, p. 223). The principal aim of this paper is to explore Goffman's dramaturgical framework and its potential for application to the field of outdoor education, rather than pedantically recount precisely what happened to whom, at what time, on a particular day. As it was unlikely that one empirical case would have yielded all of the analytical opportunities needed to explore Goffman's concepts, we decided that the most sensible course of action was to construct a fictional, yet entirely plausible, case based on extensive ethnographic experience.

The fact that the stories that we will tell are grounded in our own real life experiences of outdoor education practice, enables this to be what Frank (1995) calls a "sociology of witness" (p. 23). Following Frank, we believe that the telling of such stories enables the reader to not only think about the narrative, but also to think with our story. Thinking with stories can heighten our perception of the experiences of others in a way which may help us to reflect on our own practice and experiences. Indeed, "to think with a story is to experience it affecting one's own life and to find in that effect a certain truth of one's life" (Frank, 1995, p. 23).

\section{The fictional case study}

The fictional case study being analysed is a weekend rock-climbing course, taking place in the Peak District of England. This course is optional for the participants, all of whom are second year undergraduate physical education students at the fictional Denby University. The climbing takes place at Castle Crag, which is a 20-minute walk away from the self-catering bunkhouse where the students and staff are staying.

Some of the 12 participants have climbed and abseiled before, but others are complete novices. The university has provided all technical equipment. Of the two instructors, Pauly is a university lecturer with the highest UK qualification for rock climbing, and Lesley is a school teacher who has recently qualified as an entry-level climbing instructor. The story focuses specifically on four characters: Pauly, Lesley, and Scott and Eric, who are two of the 12 students.

\section{Act 1, Friday evening at the bunkhouse: The information game}

It was a Friday evening in September, when there was still some daylight filtering on to their spartan bunkhouse in the Peak District. Pauly, the head climbing instructor for the weekend, came into the common room and greeted everyone with a big smile and his trademark sarcasm. He had met a number of the students the previous autumn while running the University's hill-walking course.

"Back for more are you? Boy, you lot must be gluttons for punishment. I thought I did my best to put you off the great outdoors last October, when we were traipsing around The Glyders in horizontal rain!"

"Seriously though, it's great to see you folks. We've got a great weekend lined up for you - lots of material to cover. But first, I want to introduce Lesley, who'll also be working with us this weekend. Some of you may know Lesley as a Denby Uni legend. That's right. She's a graduate of the esteemed programme that you're on. In fact, Lesley's introduction to climbing was what...? Five...?"

"Six years ago - on this very course," chimed in Lesley, with a wink. Since then, Lesley had become heavily involved in climbing, and climbed at a very high standard - even higher than Pauly had done at the height of his powers. She was new to climbing instruction, however, and had only recently obtained her SPA (single pitch award). This is the minimum qualification needed to teach rock climbing to beginners in the UK.

After Pauly had outlined the basic structure of the weekend to the group, he explained how - before everyone headed off to the Red Lion for a pint - it was important for the instructors to find out two things from each person in order to cater to their needs: what they were interested in learning over the next couple of days, and what, if anything, they were afraid of or concerned about.

Almost everyone stated how they wanted to learn some knots and how to belay (protect a climber with a rope and friction device), do some climbing, and try an abseil. Four people spoke of how they were afraid of heights and were worried about being near cliff edges and being high up on climbs. Eric sat quietly, aware of his physical limitations when compared to the rest of the group, and wondered what role he might play in the coming days. Then it came to Scott's turn to speak.

"I want to climb Sunset Crack," he stated boldly. "I tried it last summer and came very close to doing it without falling (on the rope). It's rated E1, but I should be able to do it now, after all the time I've spent at the indoor climbing wall over the last few months." Scott appeared laid-back as he announced his intentions to the group, while clutching the latest copy of Climber magazine. 
"Sunset Crack, eh? Ambitious..." nodded Pauly. Although Scott clearly appeared to possess some physical ability for climbing, Pauly suspected that the lad's ropework, such as placing protection and building anchors, was very limited. Pauly, a seasoned climber and mountaineer, considered rope-work and experience-based judgement to be at least as valuable as one's physical brawn and ability to "muscle-up" a climb that posed little risk (e.g. one that was indoors and protected by bolts set into walls).

Scott possessed that self-belief and cockiness that further unsettled his already nervous friend Eric, while reminding Pauly of himself in his younger days. The young pretender had his own harness, rock shoes, and chalk-bag, and considered himself a climber. For Scott, climbing Sunset Crack would be further evidence of this - even if it was climbed on a top rope ${ }^{2}$.

Lesley was surprised that Scott had made such a statement of intent in front of other people. She had climbed Sunset Crack a number of times herself, more recently "leading" the climb (i.e. placing aluminium wedges and cam devices into cracks as she ascended). This was "real" climbing, as many traditionalists would say. Still, Lesley had her own concerns for tomorrow. These revolved not around climbing, but teaching climbing.

Despite being a secondary school PE teacher and a gifted climber, Lesley had little experience of teaching on formal climbing courses. As a person who was used to being thorough and well-prepared, she couldn't help feeling somewhat ill-at-ease in her role of climbing instructor. In fact, she felt a bit like an impostor-like someone who hadn't "earned her stripes". It was hard not to feel this way next to Pauly, who had the highest mountaineering qualification in the UK and had been taking people into the hills as his fulltime occupation for the best part of 25 years.

Determined not to come across as the novice instructor, she decided to try and do some last minute honing of her teaching skills. Even though everyone had put on their head-torches and wandered down the lane to the pub after the meeting, Lesley brewed herself a cup of tea, got out a rope, and spent the next two hours alone in the bunkhouse. She practised tying a figure 8 and a bowline with one hand, re-assured herself that she could teach a clove-hitch and an Italian hitch - each in two different ways, and finally, went over belaying blind-folded on her left side. Even though Lesley knew these rope tricks were superficial and for "show," she also believed, deep down, that she was very competent. Still, she desperately wanted the students to think that she was a seasoned instructor, who had "been around the block."

2. A top rope is a climb where the anchor (and the rope holding the climber) is above the climber, so a fall is rendered virtually devoid of risk - as long as there is not too much loose rope in the system.
On the first night of the climbing course, the 12 students and two instructional staff commenced what Goffman (1959) calls an "information game" (p. 8 ). When a person enters a social situation, they will want to learn about this situation (Goffman, 1959). In order to fully understand the facts of a given situation, they would need to know all of the related social information about the others present. As all of this information is rarely available (particularly not within the first few moments of meeting), people will "employ substitutes - cues, tests, hints, expressive gestures, status symbols, etc. - as predictive devices" (Goffman, 1959, p. 249). Goffman believes that it is through these expressive gestures that humans offer or withhold information about themselves. Although the students who arrived at the bunkhouse on this Friday night had known each other for over a year, they had little information about each others' climbing backgrounds. The instructors felt that it was necessary to find out about these backgrounds, as this would help them cater to a group of mixed abilities. They attempted to catalyse the information game by asking students to share with the group specific aspects of climbing that they hoped to learn during the course, as well as sharing any elements of the programme that were a source of fear or anxiety for them.

What unfolded during the students' responses was a form of "impression management" whereby individuals engaged in "the over-communication of some facts and the under-communication of others" (Goffman, 1959, p. 141). Specifically, these budding climbers attempted to manage "the impression that they give to others in order to appear in as favourable a light as possible" (Donnelly, 2002, p. 95). As with other interactionists (see Mead, 1934, Blumer, 1969, Cooley, 1964), Goffman sees the self as a product of social interactions, which he regarded as performances between actors and audiences. The self, then, is the "product of a scene" and not the "cause" of it (Goffman, 1959 , p. 252). Reality, for Goffman, can be seen as a fluid, ephemeral concept that is directly shaped by humans' interactions with each other. Beyond this, humans have different characteristics of themselves that they reveal to, and conceal from, other people. According to Goffman, this impression management is fundamental to the effective presentation of self.

Beyond managing the impressions that are projected to audiences, Goffman (1959) claims that communicative acts have moral implications. Implicit in an actor's performance is a moral demand that the observers treat them as if they possess all of the characteristics presented to the audience, and that they "take seriously the impression that is fostered before them" (Goffman, 1959, p. 17). For example, as Scott communicated his belief in his ability to complete Sunset Crack, he made an implicit claim that he possesses certain characteristics and, therefore, has 
the "moral right to expect that others will value and treat him in an appropriate way" (Goffman, 1959, p. 13). In most cases, the audience will happily accept the performance presented to them, particularly if the performer (or performance) is unfamiliar (Goffman, 1959).

During each performance that an individual presents to a specific audience, they will use "expressive equipment" that is "intentionally or unwittingly employed" (Goffman, 1959, p. 22). Each role that a person plays involves presenting a front, which comprises clothing, gestures, and speech patterns. We suggest that rock climbing is a domain that is particularly suited to discussions of expressive equipment, as much highly specialised and technical equipment is needed. Participants on the weekend climbing course were invited to bring their own equipment with them, and Scott had brought enough to suggest that he took climbing quite seriously. The use of such props often serves to symbolically enhance credibility in the role being played (see CasselmanDickson and Damhorst, 1993; Pike, 2004; Solomon, 1983). Previous studies of novice male climbers indicate that it is those like Scott who lack experience and competence, who will sometimes deliberately misrepresent their real identity and ability through the wearing of role-appropriate clothing (see Donnelly \& Young, 1999). Whether Scott's front was meticulously crafted or not consciously considered, it gave a clue to his audience about what kind of performance should be expected. Audiences come to expect a "confirming consistency" (Goffman, 1959, p. 24) between a performer's appearance (Scott's specialist equipment) and manner (a confident and successful ascent of Sunset Crack). This consistency enables people to "have, or be in, or maintain face" (Goffman, 1967, p. 6).

Some people believe in the roles they are playing more than others. On one extreme, performers may be fully convinced that the impression that they are projecting is "the one and only reality" (Goffman, 1959 , p. 80). On the other extreme, cynical performers take pleasure in deluding their audiences for the purposes of self-interest. Regardless of how much an actor believes in the role they are playing, successful performances depend on the witnesses believing that the actor is sincere. Lesley was the least experienced and most recently qualified of the two instructors. Her private rehearsal of techniques while others were in the pub was because she did not want the students to think that she lacked experience or was fumbling her way through a learning period (Goffman, 1959). As a newly qualified instructor, it was important to Lesley to manage the impression presented to her audience the next morning as a polished package of poise and proficiency (Goffman, 1959).
Besides appearance and manner, one's front also comprises the setting (Goffman, 1959). This might involve the furniture and décor of a living room or, in this case, a bunkhouse on the Friday night to be followed by a small crag with a variety of climbing routes and related equipment the next day. What is intriguing to the analysis of rock climbing is that some aspects of the setting may be more "public" than others. Goffman (1959) refers to this in terms of regions: the front stage where the performance is presented, and the back stage where a routine is prepared and aspects of self normally suppressed in public might make an appearance.

As the night before Scott had made a confident front stage claim to be a strong climber, will he confirm this claim by successfully climbing a difficult route in the presence of a large audience? Meanwhile, will Lesley's rehearsals and facing of her fears on the back stage enable her to manage "an impression of infallibility" (Goffman, 1959, p. 43) on her debut performance as a teacher on the front stage on the following day?

\section{Act 2, Sunset Crack: The (misre)presentation of self}

On the Saturday morning, Pauly and Lesley took their mugs of coffee outside the bunkhouse in order to have a private, informal meeting about how the day would be organised. They decided that the day would focus on people trying lots of different climbs and learning basic skills, such as climbers tying into the rope and their partners protecting them with a belay (friction) device. The discussion inevitably turned to Scott, with Lesley remaining as intrigued (if not irked) by Scott's statement about wanting to climb Sunset Crack as she was the night before.

"That boy needs to be brought down a peg," she muttered. "He thinks he's God's gift. How I'd love him to see him try and climb Sunset Crack and get his arse kicked by the rock. I don't want to see him hurt or humiliated - just given a little reality check."

Pauly grinned as he sipped from his insulated mug, "I'm sure we can arrange that."

By 9:30am three ropes hung down the rock faces from anchors that were carefully constructed by Pauly and Lesley. Each rope ran through two locked carabiners at the top of the climb, and had both ends on the ground. Lesley's rehearsals from the night before paid off, as she was able to teach introductory rope work as if she'd been doing it for years. After a morning spent learning to tie into the rope (for the person climbing) and learning to belay with a friction device (for the person on the ground to take in the loose rope as the climber ascended), it was time for lunch under the shade of an oak tree, near the bottom of the crag. Once everyone 
had unpacked their lunches, Scott asked Lesley if he could go and attempt Sunset Crack with Eric as his belayer. Lesley was quick to agree, and told them that she'd meet them at the base of the climb once she'd grabbed a sandwich. Luckily, an anchor that was already being used on an adjacent climb could be used as a top rope on Sunset Crack.

"Take in! Take in!" were the cries from Scott down to Eric. Scott was halfway up the climb and his forearms were screaming from the build-up of lactic acid. A tight rope from Eric would provide some welcome support for his waning strength.

"Eric, just lock me off and hold me here for a couple of minutes. The crux of the route is coming up and I need to shake out my arms a bit."

Lesley smiled to herself as she saw that the hopes she had earlier expressed to Pauly had been fulfilled, as Scott was obviously out of his depth. After what felt like an eternity, Scott started to move again, only to take another rest just two metres higher. At this point, Lesley walked up the path at the side of the crag so that she could watch from the top. Scott noticed the two eyes now gazing down upon him.

"My arms are trashed from all the weight training I did this week. I'm hoping to be selected for the English Universities Rugby Squad."

"You're such a 'guy', Mr. Willoughby. Good climbing is all about footwork and balance, not doing a series of chinups!"

\section{"Yeah. Whatever."}

"Seriously! Just look down below your left knee. See that notch? Jam your left foot in there and stand up - you'll really have to trust your foot placement. That'll help you reach this little pocket up here. Once you get your hand in there and move your right foot up to this little ledge, you'll be sailing."

"Aye aye, Cap'n," murmured Scott facetiously. Still, he was thankful that he now had a strategy to finish the route, as opposed to continuing to grunt and muscle his way up on a taut rope, section by section.

In the end, Scott was able to get to the top of the fabled Sunset Crack, but not without Lesley pointing out a sequence of key moves and not without the strength and patience of his partner Eric, who had been hauling attentively on the rope for almost half an hour.

"Nice one, man. You've climbed Sunset Crack," Lesley exclaimed.

Scott, visibly exhausted, was less convinced: "Climbed? Perhaps in terms of getting to the top - yeah, maybe. But it wasn't pretty."
At the beginning of the day, Lesley had effectively said that she would like to see Scott discredit himself by not being able to complete a hard rock climb - one that any self-described "strong climber" should have been able to do. During Scott's climbing performance, he was struggling (as Lesley had expected) and was obviously "caught out in a misrepresentation" (Goffman, 1959, p. 244). Yet ironically, it was Lesley who stepped in when she realised that Scott was a "beginner, and more subject than otherwise to embarrassing mistakes" (Goffman, 1959, p. 232).

As Scott struggled, Lesley (despite being secretly pleased that Scott was incapable of climbing the route without assistance), decided that it was necessary for her to employ practices to "save the show" (Goffman, 1959, p. 212). As Lesley knew the route well, she was able to point out two key holds on the rock that were vital for Scott to use in order to complete the climb. In this instance, Lesley was the audience who showed extra consideration and consciously made it possible for Scott to correct a disruption to his performance and saved him from humiliation. Even though Scott had misrepresented the facts of his climbing ability, he was fortunate in that he did not "leave himself in a position from which even the lamest excuse and the most cooperative audience...[could not] extricate him" (Goffman, 1959, p. 234), and so could maintain his moral expectation of his peers - to be treated as a serious climber.

As actors' roles develop within a given social situation, they must take care to sustain their performances (Goffman, 1959). Having spent time rehearsing her skills on the Friday evening, Lesley is able to confirm and strengthen her identity as a competent instructor initially by effective teaching and demonstrations in the morning, and then by helping Scott in front of an audience of other students. Lesley's display of slick rope-work was a way of maintaining her impression of the seasoned rock-climbing instructor, and during this performance each student may have been thinking, "I am using these impressions of you as a way of checking up on you and your activity, and you ought not to lead me astray" (Goffman, 1959, p. 249). The students have little option but to believe that Lesley's projected self is one in which she fully believes, as her actions support her projections.

In contrast, Scott's struggle with the route, following his claim of being a competent climber, meant that there is a discrepancy between the idealised version of himself that he had hoped to present to his audience and the actual self presented. Following Goffman (1959), Scott's performance has been disrupted and consequently he became "flustered, ill at ease, embarrassed, nervous, and the like" (p. 212). The intrigue lies in the ways in which people counter and minimise these disruptions to the impressions they are projecting; in Scott's case, his claim of tiredness was 
an attempt to "conceal or underplay" (Goffman, 1959, p. 48) his lack of technical ability. This resonates with Goffman's suggestion that individuals use "defensive and protective practices" in order to "safeguard the impression fostered by an individual during his [sic] presence before others" (p. 14). While Lesley has simultaneously managed an effective presentation of self as a competent instructor and enabled Scott to safely complete his climb, Scott has experienced a disruption to his climbing biography. Scott will now need to repair his climbing identity, and this may have implications for his future outdoor education experiences and those with whom he engages on these activities.

\section{Act 3, Packing away equipment at the crag: Saving face}

Lesley's voice came over like a sergeant's: "OK troops! It's 4 o'clock and we need to break down all of the anchors, re-rack the gear, and coil the ropes."

Eric's day had been dominated by belaying Scott on his ascent of Sunset Crack, after which he had finally managed to coax himself down his first abseil in order to gain some personal climbing experience. When he finally had a spare minute to himself he wandered off for a toilet break, just before Lesley's call to pack up the gear. Eric had a reputation for being a tireless helper, as illustrated in his patience with Scott, and he often assisted his tutors far beyond what was expected or necessary. He was not too naïve to see that it was a way of ensuring that he received praise in an environment where he otherwise might not due to his relative lack of physical prowess.

Bit by bit, the gear was brought back to bottom of the main crag, re-organised, and packed away into people's rucksacks. When Eric returned from his toilet break, he appeared genuinely disappointed to find that all of the work had been done without him.

"Oh no!" he gasped. "Have you already packed everything away? I am so sorry that I wasn't here to help."

"No problem man, we've got it," replied one of his classmates. "Please?"

"Here, let me take these ropes," insisted Eric.

The sergeant's voice piped up once again - this time in her best posh accent: "Right chaps. Down to the mini-bus. Double quick now!"

Eric was still concerned that people might have thought that he was not contributing to the team at his normally high level. He was particularly careful to ensure that he was the last student down from the crag and that he was visibly carrying more than his fair share of equipment - three heavy
50 metre ropes. Tired from belaying Scott for so long and still shaking from completing his first abseil, Eric stumbled under the weight of the ropes, fell, and twisted his ankle.

As with Scott's loss of face on Sunset Crack, Eric also recognised a variance of the self he presented in this situation with his expected behaviour. Following Goffman (1959), humans draw on observation in order to try to understand the social situations in which they find themselves. Even if all performers act with (what they believe to be) complete integrity, as was the case with Eric, there remains the possibility of misrepresentation. In instances where a performer is out of face, they may experience embarrassment that others "view one's presentation of self as inept" (Shott, 1979, p. 1325) and this may lead to "altruistic or reparative acts" (p. 1327) to save face and manage the impression of their self. In Eric's case, his concern that he might be perceived as having deliberately left the scene to avoid extra work led to the altruistic act of carrying an additional load by way of "engineering a convincing impression" (Goffman, 1959, p. 251) for his audience, just in case they had formed an incorrect impression of him - one that was inconsistent with past performances. This example shows how humans make efforts to manage impressions "in the face of a multitude of potential disruptions" (Goffman, 1959, p. 254). Eric risked his physical well-being in order to maintain his social identity. Outdoor education instructors should be aware that this might also manifest itself in students like Scott taking greater risks on the rock face in order to save face following a failed performance. The consequences of such risk-taking may be dangerous for both the climber and others with whom they interact in the activity (for further information on risk taking among male rock climbers, see Robinson, 2004).

\section{Conclusions}

Throughout The Presentation of Self in Everyday Life, social interaction is likened to an "information game of concealment, discovery, false revelation, and rediscovery" (Goffman, 1959, p. 8). We would argue that such an understanding of Goffman's dramaturgical framework has useful applications in the field of outdoor experiential education - particularly where outdoor activities are used to elicit discussions about participants' social interactions.

Goffman has provided us with a vocabulary to uncover the micro-world of social interaction (Scheff, 2006), and outdoor educators may find it helpful to use some of this conceptual language (e.g. fronts, impressions, disruptions) in activities that involve helping people gain a greater understanding of how their sense of self may be heavily influenced by the company they keep. The area of personal and social 
development in outdoor education is particularly suited to this kind of analysis, as it often focuses on how participants' attitudes and actions shape their social contexts while being shaped by them. As with other work on the social construction of the self in an outdoor education context (see Beames, 2005; Pike \& Beames, 2007), Goffman's (1959) framework explains how "the self does not derive from its possessor, but from the whole scene of his [sic] action" (p. 244). Goffman's fascination with the subtle complexities of face-to-face human interaction offers outdoor educators an accessible explanation of how participants can only understand their own thoughts, actions, and feelings in the context of the social group in which they are interacting. In particular, our fictional case study demonstrates how outdoor education courses may elicit circumstances where people negotiate having face (Lesley), having wrong face (Scott), and being out of face (Eric), along with the various attempts of each of these actors to save face.

Following Birrell and Donnelly (2004) we would argue that "it is possible and desirable to reclaim Goffman as a relevant social theorist for sport" (p. 56). Goffman (1959) was clear that the concepts outlined in the dramaturgical framework "can be applied to any social establishment" (p. 239). The field of outdoor education appears to be an example of what has been called a "natural laboratory" for understanding human behaviour, in which the practices and concepts of life characteristic of the contemporary world are displayed (Smith, 2006, p. 14). The fictional story presented in this paper, based on our years of experience in the field, indicates to us that outdoor education is especially ripe for further and deeper examination through this theoretical lens that is almost 50 years old. First, there is much scope for outdoor education courses to explicitly use The Presentation of Self in Everyday Life as a framework for their activities, and second, empirical data collected from these courses may yield findings that enrich curricular and pedagogical approaches in the outdoor education sector.

The dramaturgical framework has been offered not as a definitive sociological explanation of outdoor education practice, but as theory that may help practitioners see their work in a different light. Our assumption is that this paper was only worth writing if the theory has relevance and applicability to what is happening on the front-line. We hope that some outdoor educators will consider using this framework as a foundation for healthy debate, which will ultimately yield stronger and more meaningful educational programmes.

\section{References}

Allison, P. (2002). Values, narrative and authenticity: A study of youth expeditions in the 1990s. Unpublished PhD dissertation, University of Strathclyde.

Andrews, K. (1999). The wilderness expedition as a rite of passage: Meaning and process in experiential education. Journal of Experiential Education, 22(1), 35-43.

Barone, T. (1997). Among the chosen: A collaborative educational (auto)biography. Qualitative Inquiry, 3(2), 222-236.

Barone, T. (2000). Aesthetics, politics, and educational inquiry. New York: Peter Lang.

Beames, S. (2005). Expeditions and the social construction of the self. Australian Journal of Outdoor Education, 9(1), 14-22.

Bell, B. (2003). The rites of passage and outdoor education: Critical concerns for effective programming. Journal of Experiential Education, 26(1), 41-50.

Birrell, S., \& Donnelly, P. (2004). Reclaiming Goffman: Erving Goffman's influence on the sociology of sport. In R. Giulianotti (Ed.), Sport and modern social theorists (pp. 49-64). Basingstoke: Palgrave MacMillan.

Blumer, H. (1969). Symbolic interactionism: Perspective and method. Berkeley: University of California Press.

Casselman-Dickson, M., \& Damhorst, M. (1993). Use of symbols for defining a role: Do clothes make the athlete? Sociology of Sport Journal, 10, 413-431.

Coffey, A., \& Atkinson, P. (1996). Making sense of qualitative data. London: Sage.

Cooley, C. (1964). Human nature and the social order. New York: Schocken.

Donnelly, P. (2002). George Herbert Mead and an interpretive sociology of sport. In J. Maguire and K. Young (Eds.), Theory, sport E society (pp. 83-104). Oxford: Elsevier.

Donnelly, P., \& Young, K. (1999). Rock climbers and rugby players: Identity construction and confirmation. In J. Coakley \& P. Donnelly (Eds.), Inside sports (pp. 67-76). London: Routledge.

Frank, A. (1995). The wounded storyteller: Body, illness, and ethics. Chicago: University of Chicago Press. 
Goffman, E. (1953). Communication conduct in an island community. Unpublished PhD dissertation, University of Chicago.

Goffman, E. (1959). The presentation of self in everyday life. New York: Anchor Books.

Goffman, E. (1967). Interaction ritual: Essays on face-toface behavior. New York: Anchor Books.

Gouldner, A. (1970). The coming crisis of western sociology. New York: Basic Books.

Hunt, J. (1990). Philosophy of adventure education. In J. C. Miles \& S. Priest (Eds.), Adventure education (pp. 119-128). State College, NC: Venture.

Martin, A. (2001). 'Dramaturgy': An holistic approach to outdoor education. Australian Journal of Outdoor Education, 5(1), 34-41.

Mead, G. (1934). Mind, self, and society: From the standpoint of a social behaviorist. London: University of Chicago Press.

Pike, E. (2004). Risk, pain and injury: 'A natural thing in rowing'? In K. Young (Ed.) Sporting bodies, damaged Selves: Sociological studies of sport-related injury (pp. 151-162). Oxford: Elsevier.

Pike, E., \& Beames, S. (2007). A critical interactionist analysis of 'youth development' expeditions. Journal of Leisure Studies, 26(2), 147-159.

Rinehart, R. (1998). Fictional methods of ethnography: Believability, specks of glass, and Chekhov. Qualitative Inquiry, 4(2), 200-224.

Robinson, V. (2004). Taking risks: Identity, masculinities and rock climbing. In B. Wheaton (Ed.), Understanding lifestyle sports: Consumption, identity and difference (pp. 113-130). London: Routledge.

Scheff, T. (2006). Goffman unbound! A new paradigm for social science. Boulder: Paradigm.

Shott, S. (1979). Emotion and social life: A symbolic interactionist perspective. American Journal of Sociology, 84, 1317-1334.
Smith, G. (2006). Erving Goffman. London: Routledge.

Solomon, M. (1983). The role of products as social stimuli: A symbolic interactionist perspective. Journal of Consumer Culture, 10, 319-329.

Sparkes, A. (2002a). Fictional representations: On difference, choice, and risk. Sociology of Sport Journal, 19, 1-24.

Sparkes, A. (2002b). Telling tales in sport and physical activity: A qualitative journey. Leeds: Human Kinetics.

Tierney, W. (1993). The cedar closet. International Journal of Qualitative Studies in Education, 6(4), 303314.

Venable, S. (1997). Adolescent rites of passage: An experiential model. Journal of Experiential Education, 20(1), 6-13.

Wurdinger, S. (1997). Philosophical issues in adventure education. Dubuque, IA: Kendall/Hunt.

Zink, R., \& Burrows, L. (2006). Foucault on camp: What does his work offer outdoor education? Journal of Adventure Education \& Outdoor Learning, 6(1), 39-50.

\section{About the authors}

Simon Beames, PhD, is lecturer in Outdoor Education at the University of Edinburgh. Email: simon.beames@ed.ac.uk

Elizabeth Pike, PhD, is senior lecturer in the sociology of sport at the University of Chichester, General Secretary of the International Sociology of Sport Association, and a member of the Editorial Board of the International Review for the Sociology of Sport. Email:e.pike@chi.ac.uk 